commion among the peasants. Such are clearly traceable to the national food, gofio, which in this island is made of Indian corn.

For phthisis the Canary Islands have been proved of inestimable value, and therefore on this point nothing more need be said. The temperature throughout the year, by day and by night, varies exceedingly little. In my recently-published work on these islands I have gone so fully into this question that I need not recapitulate it here.

I should not have thus ventured to trouble you had I not been asked by some leading members of the medical profession to summarize the facts, bearing upon diseases, scattered through the pages of my book and to add thereto others which I had deemed unsuitatle for the general reader.

II Sheffield Gardens, Kensington, W., December I4.

\section{The Ffynnon Beuno and Cae Gwyn Caves.}

Mr. Smith has entirely failed to substantiate the statement made by him in his letter of December I (p. 105) concerning the drift over the entrance of the Cae Gwyn Cave, which is 20 feet in thickness and full of ice-scratched boulders, many of large size; therefore I need only say in reply that the Geological Surveyors who surveyed this district have examined the section and have had no hesitation whatever in classifying the deposits in the section with the Glacial beds of the area. In regard to the age of river drift implements as compared with those found in the cavern, which are identical with the implements found in Kent's cavern and the French caves, I need only quote the remarks of M. Lartet ("Reliquia Aquitanicx," p. 9):- "If some are inclined to attribute to the works of human industry found in the 'Diluvium' or 'Drift' a date more ancient than to those occurring in caves with a similar association of animal remains, we are obliged to remark that such a proposition, expressed as a systematic generalization, is not justifiable in any point of view."... "Caves were in truth the first shelter which primitive man would choose, whether driven by instinct or determined by reason."

When Mr. Smith calls the implements found in the gravels at Mildenhall, Neolithic, which others claim to be Palæolithic, and one most eminent authority to be pre-Glacial, I am perfectly justified in saying that the classification of such implements as defined by Mr. Smith, has no chronological value, and therefore I do not think that anyone is likely to be convinced by his arguments when he is "content to resist the idea of the preGlacial age of these caves on purely archæological grounds."

Hendon, December 23. HENRY HICKS.

\section{Distorted Earth Shadows in Eclipses.}

WITH reference to the peculiar appearance of the earth's shadow in the lunar eclipse of August 3 of this year, and noted by "H. H." and "N. C." (see NATURE, vol, xxxvi. pp. 367 anc $4 \mathrm{I} 3$ ), it may be of interest to record a similar distortion observec by Capt. A. E. Barlow, on the s.s. Nizam, at Suez, on August 23,1877 . The following entry appears in his meteorological $\log :-$

"The eclipse of August 23. The moon as seen at mid. night at Suez. Weather fine starlight. A few cir.-c. (amount 3) travelling from northward."

The shadow was irregular and jagged as in "M.C.'s" description.

Meteorological Office, December 22. Marine Superintendent.

\title{
DR. BALFOUR STEWART, F.R.S.
}

$\mathrm{N}$ the genial Manchester Professor the scientific world has lost not only an excellent teacher of physics but one of its ablest and most original investigators. He was trained according to the best methods of the last generation of experimentalists, in which scrupulous accuracy was constantly associated with genuine scientific honesty. Men such as he was are never numerous; but they are the true leaders of scientific progress :-directly, by their own contributions; indirectly, though (with rare excep-

tions) even more substantially, by handing on to their students the choicest traditions of a past age, mellowed by time and enriched from the experience of the present. The name of Stewart will long be remembered for more than one striking addition to our knowledge, but his patient and reverent spirit will continue to impress for good the minds and the work of all who have come under its influence.

He was born in Edinburgh, on November $\mathrm{r}, \mathrm{r} 828$, so that he had entered his sixtieth year. He studied for a short time in each of the Universities of St. Andrews and Edinburgh, and began practical life in a mercantile office. In the course of a business voyage to Australia his particular taste for physical science developed itself, and his first published papers :- "On the adaptation of the eye to different rays," and "On the influence of gravity on the physical condition of the Moon's surface":--appeared in the Transactions of the Physical Society of Victoria in I 855. On his return he gave up business for science, and resumed study under Kelland and Forbes, to the latter of whom he soon became Assistant. In this capacity he had much to do with the teaching of Natural Philosophy on occasions when Forbes was temporarily disabled by his broken health. During this period. in I 858 , Stewart was led to his well-known extension of Prévost's Law of Exchanges, a most remarkable and important contribution to the theory of Radiation. He seems to have been the first even to suggest, from a scientific stand-point, that radiation is not a mere surface phenomenon. With the aid of Forbes' apparatus, then perhaps unequalled in any British University, he fully demonstrated the truth of the conclusions to which he had been led by theory; and the award of the Rumford Medal by the Royal Society, some years later, showed that his work had been estimated at its true value, at least in the scientific world. In fact his proof of the necessary equality between the radiating and the absorbing powers of every substance (when divested of some of the unnecessary excrescences which often mask the real merit of the earlier writings of a young author) remains to this day the simplest, and therefore the most convincing, that has yet been given.

Radiant Heat was, justly, one of Professor Forbes' pet subjects, and was therefore brought very prominently before his Assistant. Another was Meteorology, and to this Stewart devoted himself with such enthusiasm and success that in 1859 he was appointed Director of the Kew Observatory. How, for eleven years, he there maintained and improved upon the memorable labours of Ronalds and WeIsh needs only to be mentioned here :it will be found in detail in the Reports of the British Association. Every species of inquiry which had to be carried out at Kew:-whether it consisted in the testing of Thermometers, Sextants, Pendulums, Aneroids, or Dipping-Needles, the recording of $\Delta$ tmospheric Electricity, the determination of the Freezing-Point of Mercury or the Melting-Point of Paraffin, or the careful study of the peculiarities of the Air-Thermometer:-received the benefit of his valuable suggestions and was carried out with his scrupulous accuracy.

About twenty years ago Stewart met with a frightful railway accident, from the effects of which he did not fully recover. He was permanently lamed, and sustained severe injury to his constitution. From the vigorous activity of the prime of life he passed, in a few months, to grey-headed old age. But his characteristic patience was unruffled, and his intellect unimpaired.

His career as Professor of Physics in the Owens College has been, since his appointment in 1870 , brilliantly successful. It has led to the production of an excellent treatise on Practical Physics, in which every necessary detail is given with masterly precision, and which contains (what is even more valuable, and could only have been secured to the world by such a publication) the matured convictions of a thorough experimenter as to 